\title{
Psychological and Societal Impacts of Unknown Descent and The Islamic Objective of Nasab. A Preliminary Study of Chosen Biomedical Technologies
}

\author{
Anke Iman Bouzenita ${ }^{a}$, Feryad A Hussain ${ }^{b}$ \\ ${ }^{a}$ Department of Islamic Sciences, College of Education, Sultan Qaboos University \\ ${ }^{b}$ Clinical Psychologist, Child and Family Services/ Palliative and End of Life Care, Black Country Partnership NHS Foundation Trust, UK
}

\begin{abstract}
This paper is a preliminary study on the expected implications of some chosen biomedical developments on the loss of descent (nasab), its psychological effects on children and parents, and sociological effects generally. In the first part, this paper elaborates the meaning and importance of nasab (descent) in Islamic law, under consideration of the Higher Objectives of Sharia, and explanation of some related legal rules. The second part investigates psychological impacts of unknown descent and reviews existing research in the field. The third and final part, presents five chosen scenarios i) human cloning through somatic cell nuclear transfer (SCNT); ii) surrogate motherhood; iii) IVF with sperm or egg donors; iv) anonymous milk banks; and v) mitochondria (mt) transplantation; in the light of the Islamic objective of nasab, its existence or non-existence, and possible consequences.
\end{abstract}

KEYWORDS: nasab, descent, maqāṣid al-sharīca, biomedical technologies, Islamic bioethics

\section{INTRODUCTION}

New developments in the biomedical field particularly in distinctive role in Islamic law, and in how far the assisted reproduction techniques, such as in vitro unspecified or unknown nasab of a child, as it results fertilization (IVF) babies, surrogate motherhood, and from the application of new advancements in assisted various forms of human cloning; may in some cases lead reproduction and biomedical engineering, may affect it to a child not knowing his or her descent from either the and society psychologically and sociologically? This maternal or paternal side. Biological descent may even be paper is also more concerned with the underlying hikma split between three or more biological parents, or not be (wisdom) than the 'illa (rationale) of legislation. Due to obvious at all. These new developments constitute a the lack of specific research in this overlooked field, this breach, both in quality and quantity, with previous cases paper may raise more questions than it is able to answer. where the establishment of nasab (descent) played a role. It is the authors' intention to draw more academic attention to the subject.

This research paper does not focus on attempting to identify the nasab of children with multiple parents, as The first part of the paper investigates the meaning and this would follow a different rationale. It is rather importance of nasab in Islamic law as well as its legal concerned with the question of why nasab plays such a effects. The second part gives an overview of

Corresponding Author:

Assoc. Prof. Dr. Anke Iman Bouzenita

Department of Islamic Sciences,

College of Education, Sultan Qaboos University,

P.O. Box 331, Khoudh 123

Muscat, Oman.

Tel No : +2414 3990

E-mail : bouzenita@squ.edu.om contemporary psychological and sociological research on the impacts of a child not knowing, or being deprived of, the knowledge of his origins in various settings. In the third part, the paper showcases the growing number of possibilities in the age of biotechnology and bioengineering that will lead to unknown descent or even the impossibility to trace descent to a pair of 
biological parents, one mother and father. The focus will be on five chosen scenarios: i) human cloning through somatic cell nuclear transfer (SCNT), ii) surrogate motherhood, iii) IVF with sperm or egg donors, iv) anonymous milk banks, and v) mitochondria (mt) transplantation. The conclusions highlight the most important findings.

\section{Part One: The Islamic Legal Perspective on Descent (Nasab)}

\section{The meaning and importance of nasab in Islam}

Conventionally, Islamic scholars have exerted major efforts in clarifying rules related to nasab but have hardly looked beyond the purely legal impact of (unknown) nasab, namely, the psychological and sociological aspects. A reason to this could be that cases of unknown descent were rather exceptional and limited and did not impact society much, or simply because it did not fall into the scope of their interest

Fiqh (Islamic jurisprudence) has been concerned with how to establish nasab, what are the means traditionally, and how far new biomedical techniques may or may not be reliable tools to do so. Rarely has research attempted to look into why nasab is so important, and to which extent biomedical developments can have an impact once it is widely practiced. The paper will draw on the Higher Objectives of the Shari'a for explanation of the expected impacts on future generations who run the risk of not knowing their origin.

\section{Nasab in Fiqh: Meaning and Importance}

Nasab (pl. ansäb) may be translated as descent, lineage, filiation or ancestry in English. The term is mentioned in the Qur'an in three places. "He is the One who created from water human beings and designated for him descent (nasaban) and kinship (sahran), and Your Lord is the Ever Powerful." (Qur'an 25:54; also 37:158 and 23:101). In the technical sense, nasab designates affiliation between two people through a common bond by birth, be it close or far. ${ }^{1}$

Nasab entails a number of rights; the right of a child to have a father who cares for him and supports him financially and the right to have a mother, as well as reciprocal rights of mother and father on the child. Nasab is not considered to be property and can therefore not be bought, donated or bestowed. The legal reasons to establish nasab are marriage (a valid legal marriage and a defective marriage under certain conditions) as well as istilad, a child born out of a relationship to a slave (järiya or umm walad). While the former is of relevance today through the existence of marriage, the latter has become obsolete with the seizure of slavery. Nasab is established if a child is born in a legally valid marriage even six months after concluding the marriage contract, with a rationally possible contact between the spouses. The child follows the descent of his mother's legal spouse ("The child belongs to the marriage bed” (الولد للفراش.) Motherhood is established by birth ("Only those women who gave birth to them are their mothers." Qur'an 58:2). ${ }^{1}$

Islamic Law, from the outset, lays high emphasis on nasab and fights the circumstances under which doubtful nasab may arise. In this light, Islam does not condone any sexual relations outside a legally valid marriage, without consideration of whether these relations take place with or without consent. The mere gaze at a non-related woman, which may lead to sexual attraction and interaction, is prohibited. Illicit relations come under the term "zini $\vec{a}$ " or adultery, with legal implications stipulated by Islamic law. Islam is adamant in prohibiting circumstances that may lead to illicit sexual relations ("Do not come close to adultery!" Qur'an 17:32) and implements the particular framework through its social system and system of punishments. Adultery is considered one of the most heinous crimes, deserving capital punishment (hudūd).

Islamic law recognizes the descent from the father's side through a valid marriage, an incomplete marriage (zawajj fasidid, sexual relations with a woman on the basis of a doubt (i.e., there is an initial doubt, such as the couple believing they are in a legal marriage), as well as relations with a female slave (which has ceased with the obsoleteness of slavery). As for the mother, the child's descent from her is legally established by birth. ${ }^{2}$

On the contrary, nasab is never established if a child resulted from an illegitimate relationship (zina), and the only legal mechanism to compromise the nasab of a 
child born in marriage is $l^{\prime}{ }^{\prime} \bar{n}$, which becomes effective if the husband accuses his wife of committing adultery without the availability of witnesses..$^{1,3}$

A legally valid marriage has many conditions that are beyond the scope of this paper. Among others, a marriage may be prohibited due to marriage kinship (mușạhara), consanguinity (nasab) or wet-nursing (riḍäa), as wet-nursing prohibits in marriage options what consanguinity forbids. The preceding highlights some of the aspects of the importance of the knowledge of nasab.

Scholars of the past have gone into great detail to establish the legitimacy of nasab of a child, the case of a foundling or cases of doubt. Fiqh compendia are filled with a plethora of case studies in this regard. Some of these have a rather eerie resemblance to newer developments in bioethics; such as a woman inserting sperm without having intercourse, or two men (accidentally) having intercourse with the same woman, both thinking themselves in a legal marriage relationship to her. ${ }^{1}$ In cases like these, it is apparent that Islamic legal scholars went through efforts to have the child's nasab established. This is not the case due to parochial motives of a closed society. It is rather the right of the child to have a legitimate and established nasab, and it seems that scholars were aware of the implications of a child growing up without an established nasab, even if they did not vocalize their obvious concerns.

This being said, an important methodological issue in the Islamic legal treatment of biomedical advances leading to ambiguities or loss of descent needs to be addressed. While the attempt to formally establish the descent of children born out of biomedical advances described below, even in case of their impermissibility, may be laudable to safeguard the individual rights of children involved, it may also backfire in paving the way to permissiveness in their regard, under the excuse that legal complications have ostentatiously been solved.

It is neither permissible to state the nasab of a nonaffiliated child as one's own, nor to deny the nasab of own children. The latter is considered to be one of the big sins (al-kabäir). ${ }^{1}$ Adoption, i.e. taking in a child under pretence of it being one's own, giving him one's own name, is therefore not permissible. ${ }^{4}$ The legal consequences of nasab are numerous and form a central part of the organization of society, starting from the family unit to rules of marriage, inheritance, economic rights.

A vast section of contemporary research in bioethics preoccupies itself with the usage of genetic engineering (genetic fingerprints) to assess the nasab of a child, with varying results. 5 This aspect of nasab and biomedical developments is, however, not the concern of this research.

\section{The Islamic objectives (maqāșid) in protecting nasab}

It is apparent that Islamic law puts great emphasis on the safeguarding of nasab. Nasab is obviously so significant that it requires legal protection on various levels. In reverse conclusion, one may ask what are the repercussions on the individual child, on a society, where people are, due to multiple reasons, not aware of their descent in rising numbers? And in which way may this effect be brought about by resorting to new biotechnological developments in the field?

Nasab or descent has been categorized under the Higher Objectives or maqāsid of Islamic Law, referred to in variations as nasl (offspring) or ind (honour). ${ }^{6}$ Under maqāṣid al-sharīa, scholars like Imam Al-Ghazālī understood acquiring the benefits and warding off harm in this worldly life and the afterlife. The generally agreed upon higher objectives include the protection of dinn, life, intellect, progeny and property. These are protected on different levels of strength, the most important level of necessities (darüriyāt), complimentaries (häjiyāt) and embellishments (tahsinizät).6,7

On a necessity level, the prohibition of adultery (zinā) has, within the maqāșid framework, been explained as a protection of nasab, just as the legislation of the legal rule on qadhaf (slander) has. On a more complementary level, the gaze at a non- related (i.e., non-mahram) women comes under the protection of nasab as well. ${ }^{6}$

Nasab (or nas) is protected from two perspectives, the perspective of existence and non-existence. The first perspective entails bringing about and protection of offspring through the establishment of legal marriage. The entirety of legal rules related to the family system serves this purpose. ${ }^{6}$ The second perspective entails the 
protection of offspring from being lost, diminished and displaced. Among these are those rules that serve to prevent illicit sexual relations which may in turn, lead to illegitimate offspring. 6 Some of these will be explained below.

Islam has annihilated the illegitimate forms of marriage known in the time of Jahiliyya and permitted sexual relations only within the legal framework. The illegitimacy of adultery is, on a maqāṣid level, (among others) explained with the resulting mixing of lineage or origins. The unidentified origins of children lead to the detriment of society. Siblings or half siblings may unknowingly marry each other because they are not aware of their affiliation hence entering into an incestuous relation. One of the reasons for the legislation of ' $i d d a$, the waiting period for a divorced (three months) or widowed woman (four months and ten days) to remarry, is to avoid the mixing of affiliation. 5 The rule on qadhaf (slandering women to have committed illicit sexual relations) has been established to protect nasab as well as the honour of women. With unknown descent, children (as well as parents) lose their rights to being taken care of, inheritance and other economic rights. These are the obvious results of unknown descent.

However, there may be less obvious and more intricate wisdom to the establishment of descent than the immediate legal effects. The right to grow up among people with shared appearance and characteristics, a shared family history, and in a family unit, which all create a sense of belonging and safety. All of these may be denied to a child with unknown or uncertain descent.

\section{The case of unknown nasab (descent)}

Unknown descent has a plethora of different possibilities, from - to mention some conventionally known cases - a foundling whose origins are unknown, a child born in a marriage but with a biological father other than the mother's spouse ("milkmen's children" or “cuckoo's children"), children being mixed up immediately after their birth, children abducted in early childhood, and adopted children. Again, every case may have different permutations, with either child(ren) or parent(s) knowing or not knowing about their biological parents, relations and family history.
Islamic law has treated the scenario of unknown descent in case studies related to the foundling (laqit). A laqit, in summary of different definitions, is a child whose parents have abandoned him for economic fears or to escape charges of adultery (according to the Hanafis), a human child not knowing his father or owner (according to the Shafi'is) or a child beneath the age of distinction who knows neither nasab nor ownership, who has been discarded on the road or lost his way between the ages of birth and distinction, according to the Hanbali school. ${ }^{8}$ Nasab can, according to the Hanafi, Shafi'i and Hanbali schools, be attributed to any suitable free Muslim person, irrespective of whether he found the child or not. This view follows the rationale that the child benefits from care, education, and is saved from perishing, while the person whose nasab he is attributed to benefits from the child in this world and the next. ${ }^{8}$ The Maliki school follows a different view, imposing as a condition that the person forwards evidence of fathership. ${ }^{8}$ Taking a foundling in may come under the category of individual or collective obligation (fard 'ayn or fard kifäa), according to the circumstances. ${ }^{4}$

These case studies, in summary, attempt to formally establish responsibility for the foundling, the child whose descent is unknown. The case of the foundling cannot be identically transferred to the scenarios described below. In the traditional case of a foundling, a child has the natural biological descent of two parents, but this descent is unknown due to the child being abandoned. The cases under consideration here differ in that descent may transcend conventional biology.

New advancements in assisted reproduction and biomedical engineering transcend what is so far known of mixing of lineage, as cases may become so complicated that even scientists may find difficulty in assessing the lineage or descent of a child. As a consequence, the traditionally asked question about (biological) mother and father may be beyond clear-cut answers and lead to an amount of uncertainty. Given that research questions are very much dependent on the worldview and experience of researchers, the questions of concern to us may not have been asked yet. The manifold aspects of psychological and societal effects of children not knowing their parents are difficult to assess, as there is little research with supplementary 
conceptual debate on the relevance of the concept to modern day life.

\section{Part Two: The Psychology of Descent}

\section{Psychological impacts of unknown descent}

Knowing our descent is assumed a to be a natural part of one's life, so much so that little consideration is given to those individuals who have no knowledge of their parental heritage. Considered to be limited to children who are adopted, the non-disclosure or parental identity by legal and social services is an issue affecting only a minority percentage of the population. However, in addition to adoption, medical advancements in assisted reproduction techniques coupled with an increase in utilization of such services means that the once small group of people who were unaware of their descent is now growing. As those children develop into adulthood, the psychological problems caused by unknown descent are being recognized as an influential factor in psychological well-being in individuals facing this challenge.

\section{Processes limiting research}

As mentioned above, due to the percentage of people affected by this issue, perhaps not surprisingly, there is a paucity of research in this area and little is known about the experience of people living with unknown descent. Research exploring the general impact of living with unknown descent focuses on medico-legal, various aspects on the individual health, history and prognosis as well as inheritance rights etc. Whilst this fits into a wider human rights concern for the individuals involved, little attention is given to the more profound and arguably more debilitating impact on the resultant psychological problems i.e. children's social-emotional adjustment, and adult mental health. ${ }^{9}$

Whilst, the impact of unknown descent may seem clear to those who have the knowledge and make informed decisions around their relationships, this is not the case with those individuals who are prevented by process and systems put in place to secure the confidentiality and protect the rights of the adults involved. Furthermore, since historically reproductive assisted technologies and adoption services have generally supported the idea of non-disclosure it means there is no recognition that the children involved in these processes are even identified as having potential problems.

The justification of this is bound up issues of privacy, confidentiality and human rights. Ironically, a study found that when disclosing birth circumstances where children were conceived using a donor, the children responded in a neutral way and most parents did not find disclosure to be problematic. ${ }^{10}$ So there is notable dissonance between research and individual experience.

The lack of attention in the literature to the child's experience is echoed in Rowland's Australian study that explored the experience of field workers around the lack of focus on children due to the issues of non-disclosure and privacy for adults. ${ }^{11}$ It was found that professionals themselves felt that the secrecy around this issue should be abolished. Rowland further concluded that all members of a society are affected by the codes of secrecy currently operating and the 'rights' of all members of that society need to be considered. ${ }^{11}$ The conclusion being a pertinent message for both professionals and parents.

An important study looking at the issue of social histories explored the reasons parents themselves (as so far we are saying it is organizations and legal bodies) do not disclose parental descent. ${ }^{12}$ These were found to exist along a continuum which encompassed: 1) Parents who do not intend to disclose; 2) Parents who are uncertain about what they want to do, or confused about the best way to disclose; and 3) Parents who have disclosed descent from the beginning of their new relationship with the adopted child. Kirkman concluded from interviews with offspring, in the context of human rights issues and the increasing salience of genetic knowledge, that disclosure to offspring before adolescence should be encouraged. ${ }^{12}$

Cultural differences also contribute to the problem of 'privacy' in justifying unknown descent. In her research on stigma around adoption in Indian communities, Bharadwaj found that the need for secrecy was to protect adoptive families from having to face or explain the presence of a third party in the new parental relationship. The researcher noted that this raises 
questions regarding the culturally binding idea of the 'married body' and their child. ${ }^{13}$

We see then that the research is limited by the role of privacy/secrecy in the adoption process and the related formal withholding of information, which naturally does not allow flexibility in further exploration. The issue is further compounded by cultural differences.

\section{Theoretical explanations}

There is no single comprehensive theory that explains or explores the impact of unknown heritage on development. Understandably, existing theories assume this knowledge and are built on future psycho-socialphysical development of the child, their relationships and their experiences of the world. Similarly, specific heritage theories refer to wider cultural, religious, and/ or social heritage as opposed to biological heritage. Again, we see in the theory that knowing one's heritage is part of assumed knowledge about life.

An early theory by Wellisch introduced the concept of 'genealogical bewilderment' although, the theory itself is not without its controversy. ${ }^{14,15}$ Wellisch described the emotional state of a child living with unknown heritage: "A ...child is one who either has no knowledge of his natural parents or only uncertain knowledge of them. The resulting state of confusion and uncertainty fundamentally undermines his security and his mental health". 15 The definition was important in that it made a distinction between partial and complete knowledge of descent - highlighting the fact that even some knowledge makes a difference to the emotional state, irrespective of the quality of information.

Whilst the concept of 'genealogical bewilderment' has not been further developed beyond this original theory, it has been widely used to support the idea that there are psychological consequences to withholding parental descent, and the term continues to be used today.

However, review of this early theory has raised concerns around the implications of the frequent use of the term to explain the experience of unknown descent with much of the critique questioning the assumptions underlying the idea that there are always negative psychological effects caused by unknown descent. ${ }^{16,17}$ Leighton, in fact argues that the term 'genealogical bewilderment' contributes to the distress faced by children/adults living with unknown descent and 'does more to add to the problem and less to explain the experience'. ${ }^{16}$ However, it is important to note that Leighton does not deny there are problems for children of unknown descent, but argues that it is not an absolute consequence. She further states that much of the work in this area is negatively biased by cultural beliefs around definitions of family, as well as by gender and racial bias. ${ }^{16}$

Ravitsky responds that whilst it is accurate to state that not all children of unknown descent experience negative psychological effects, they may indeed suffer harm if their right to access this information is violated, as it deprives them of the liberty to choose what meaning they assign to the genetic components of their identity and relationships, a choice others in society have. ${ }^{17} \mathrm{We}$ can infer then that Wellisch's early description has problems regarding its application and does not allow for differences in definition or for individual cultural and social experiences of unknown descent. Debates aside, all these researchers agree that the experience of unknown descent is one which has potential to have a negative impact on the psychological well-being of the individual involved.

\section{Explaining the negative psychological impact from the view of social psychology}

Social psychology may enable us to gain an insight into this experience and explain the extent of the impact more comprehensively. Originally used to explain trauma, an adaptation of the theory of 'shattered assumptions' by Janoff-Bulman, may help us understand the experience for individuals living with unknown descent. ${ }^{19}$

'Shattered assumptions' theory explores the effect that negative events have on our lives, specifically significant events constituting trauma. Janoff-Bulman posits that any traumatic event challenges three core assumptions: a) overall benevolence of the world, b) meaningfulness of the world, and c) self-worth. ${ }^{19}$ Understandably, when an individual discovers or lives with the knowledge that their biological parent is unknown and, in many cases, intentionally concealed from them, these beliefs will be called in to question. 
The theory is pertinent here, because it explores the assumptions of those aspects of life which we do not pay attention to i.e. the idea of known parental heritage being a core assumption for most of us. It suggests that these beliefs are what make up our "assumptive world," defined as "a strongly held set of assumptions about the world and the self which is confidently maintained and used as a means of recognizing, planning, and acting". ${ }^{20}$ As such, these beliefs are not ones that we are consciously aware of or likely to change, since they are not often in our daily consciousness. Clearly in the case of unknown descent, it may be argued that the three assumptions are duly shattered, because in many cases those trusted parents and systems, in spite of good intentions, are seen to collude with the 'triggering traumatic event' through their protection of (only) the adults involved in what Bharadwaj calls "the conspiracy of silence".13

In building on this criticism, Bruce advises a 'framework of confidentiality' as opposed to exclusion or withholding of information in order to protect both parties ie adult and child. ${ }^{21,22}$

\section{Research}

General research in this area is limited to personal accounts, legal concerns (often about loss of inheritance rights and significance of related knowledge of medical histories with only a passing reference to the (related and independent) psychological impact of unknown descent. Other research focuses on the relationship between mother and child, with the emphasis on the parent's experience, not the child's, or on mental health issues in surrogates or donors as opposed to offspring. The body of research itself reflects the lack of priority given to the individual living with unknown descent. ${ }^{21,23-26}$

Research specifically on the psychological impact of unknown descent is uncommon and specificity of factors is similarly limited. Primary problems facing individuals living with unknown descent include increased emotional vulnerability, poor psychological adjustment, and problems with self-identity. We might surmise further secondary problems as a result of these primary issues, but no research is available yet. In their research exploring psychotherapy with individuals living with unknown descent, Meerum Terwogt et al. found that those children often developed identity problems.
This results from identifying with their (imagined) version of the unknown parent, to whom they attribute all the personal characteristics that they cannot trace to others. Consequently, such characteristics are less strongly felt to be part of one's own personality. ${ }^{27}$

Tieman et al. carried out a large study $(n=1417)$ that examined international adoptees and factors associated with searching for birth parents and how this affected psychological well-being. ${ }^{28}$ Participants were divided into 4 groups: i) uninterested non-searchers, ii) interested non-searchers, iii) searchers, and ov) reunited searchers. In total, $32 \%$ of adoptees had searched. Although the majority of searchers were well-adjusted, they had more problems mainly internalizing problems, than did uninterested non-searchers. These problems, however, were not caused by the search itself. ${ }^{28}$

Exploring reasons offered by individuals searching for their unknown parent, Sobol and Cardiff included i) a desire to know their genealogical history, ii) to increase their sense of identity, and iii) to establish a relationship with birth parents. It is important to note that $32 \%$ of the samples were identified as searching for their parents. Reasons provided by non-searchers included fear of hurting either adoptive or birth parents and satisfaction with identity as children of adoptive parents. ${ }^{29}$ Bertocci and Schechter (1991) offered more direct guidance in their work on understanding common themes in the psychology of adoptees: they cited issues such as loss and attachment, envious resentment, body image and sexuality, internal controls and empowerment, and the acquisition of a sense of human connectedness. ${ }^{30}$

Müller and Perry carried out two extensive meta-studies on the adopted persons' search for and contact with their birth parents, identifying a number of trends within this group. ${ }^{31,32}$ In the first part of the research, they found that the percentage of adoptees searching for their biological parents had increased in recent decades from $50 \%$ to $65 \%$. More women than men were found to carry out a search. The authors explained this partly due to research effects and partly by the fact that women could relate to the situation more personally due to their own experiences of pregnancy, childbirth, and being mothers themselves. This is significant, as the analysis also revealed adjustment- 
related gender differences in girls and boys who had been adopted. ${ }^{31}$ Part two of their meta-analysis revealed findings related to expectations and impact of having the knowledge of descent. Whilst many adoptees were mainly interested in genealogical information, once the need for genealogical information was satisfied, many adoptees had no need to continue the relationship with their birth parents, because they found there was little in common thereafter. ${ }^{32}$ From the Islamic perspective, given that both parents and children have rights, new relations may be built in this situation. In contrast, keeping the relationship up in a non-Islamic context would remain a question of choice and may be discarded as an option.

Muller and Perry also found that adoptees and birth mothers had different expectations following new information. Adoptees saw their birth mothers as a resource for direct access to their genetic and genealogical background. For their part, birth mothers found the interaction revived the trauma of the original experience and the circumstances of separation. They experienced enquiries about the birth father as trivializing their role and their distress, which in turn impacted further information sharing and interaction. ${ }^{32}$ The analysis revealed that the long-term relationship was culturally determined, and that it ranged from basing future meetings on the unconditional bonds of motherhood to basic biological connections, with a friendship-based model somewhere in between. ${ }^{32}$ This study was important because it explored the journey from not knowing to knowing and beyond, highlighting the relationship between the two parties. However, specific psycho-social factors were not the focus and so we might only infer impact and effect. Given that the research described above is not directly looking at psychological consequences of unknown descent, but rather doing so indirectly through explorations of consequence of process, we can only be tentative about drawing firm conclusions.

\section{Benefits of known descent}

In contrast to the research highlighting problems of unknown descent, a number of studies demonstrated (both directly and indirectly) the benefits of contact, identifying and encouraging a positive relationship between adopted/surrogate families and biological parents where awareness of heritage is known. A study exploring the experiences of individuals who were seeking to discover parental descent found that age was a moderating factor: offspring who had found out about their conception after age 18 were more likely to be searching for medical reasons, whereas those who had found out before age 18 tended to be searching out of curiosity. The researchers reported that some offspring had discovered large numbers of half-siblings (maximum $=13$ ). They concluded that the majority of offspring who had found their donor relations reported positive experiences and remained in regular contact with them. ${ }^{33}$

Conversely, a study highlighting the benefits of nurturing a relationship with both sets of parents examined depression and externalizing problems of children in foster care $(n=362)$. Findings indicated that more frequent contact with the biological mother was marginally associated with lower levels of depression and significantly associated with lower externalizing problem behaviours. ${ }^{34}$ The research described above reiterates the overall positive outcome of known descent and in effect promotes the importance of transparency of parental heritage.

In short, although there is a paucity of research in the area, the existing research supports the idea that children do experience some level of psychological problems which affect their mental health during childhood and/or adulthood. This is further reinforced by health and social care services, which encourage transparency and strongly support the view that disclosing heritage is important for the psychological well-being of the child. This is not to trivialize the efforts shown by adoptive parents, but it is significant in considering the present and future needs of the individual and their psychological well-being.

\section{Part Three: New Biomedical Technologies and their Possible Impact on Nasab}

The following five scenarios of newer developments in the biomedical field will be discussed vis-à-vis their possible impact on nasab and possible psychological and sociological consequences. 
Scenario One: Human cloning and the disintegration of nasab

After the global surprise and heated discussions following the cloning in 1996 of Dolly the sheep, and the subsequent prospects of cloning human beings, most Muslim scholars as well as leaders of most other religions worldwide, declared the cloning of human beings as impermissible. The Fiqh Academy announced this verdict in 1997, as did countless scholars of figh worldwide. $35-37$

Among the main reasons for this prohibition referred to by Muslim scholars are that cloning alters human nature and aptitude (fitra), and that the makeup of humankind in pairs (sunna zawjiya) becomes undermined by cloning. Other arguments are the potential threats to the diversity which Allah has created in the universe, and that family bonds and social relationships become uncertain and questionable. The loss of the line of descent is apparent in that single question: Who are the parents of a clone?38

Somatic cell nuclear transfer (SCNT) describes a procedure where the nucleus of a somatic donor cell is transplanted into a previously enucleated host egg cell, thereby creating an identical twin to the first cell's owner. This cell could then be inserted into the womb of the intended mother and be carried to term. ${ }^{39}$ On a more futuristic notion, the pregnancy could be brought to term in an artificial womb with no natural birth mother involved. The surrogate mother may or may not be related to the owner of the cell, may be the owner of the somatic cell herself, and may or may not be identical to the egg cell donor. One or both genetic parents could be deceased by the time of birth. ${ }^{40} \mathrm{~A}$ multitude of variations exists for this scenario, with all the mindboggling uncertainties and ambiguities entailed for the rules of nasab.

There is no doubt that a cloned human being, in essence a late-born twin, would have a unique personality, lifespan, and be endowed with a soul. This is not the subject of our research. A cloned human being would have the same genetic parents (and their respective kin) as the donor of the cloned cell, share genetic material even if to a minor extent with the egg cell donor, and have an unidentified relationship to the birth mother.

Is nasab traced back to the genetic parents, with all the legal implications involved? How about the birth mother's status? Is she the legal mother, based on the Qur'anic precept that 'Your mothers are only those who gave birth to you" (58:2)? Is she a second mother, comparable to the status of a foster mother? Or would nasab be awarded, in the well-known attempt to navigate fiqh circumstantially, to the social parents of this child? It is foreseeable that secular legal systems will most likely opt for this solution. ${ }^{41}$ Islamic law is, however, bound by the texts of revelation. Adoption is not a legal option in Islam, and establishing nasab has far-reaching consequences. ${ }^{36}$

There are to date no verified reports on the successful cloning of human beings. The manifold legal implications, not only from an Islamic point of view, with regard to guardianship, inheritance, rights to education, marriage, and so forth, can only be imagined. Research on the psychological implications of the human clone and society at large does not as yet exist. In light of the existing research on unknown descent, we have to assume that factors such as the impossibility of tracing back (genetic) parenthood, and the breaking up of social ties, in addition to the legal implications and confusion involved, affects a person negatively, and the consequences for society are unknown.

\section{Scenario Two: Surrogate motherhood and how it affects the rule of nasab}

The basic meaning of surrogacy is that a woman, on behalf of another party, carries a baby to term. The surrogate mother may agree to this for economic or altruistic reasons. The parents-to-be, who could be married, single, hetero- or homosexual, may decide to have a surrogate mother to avoid the hardships of pregnancy and delivery, or due to medical inability to carry a child to term. Forms of surrogacy vary. There is traditional surrogacy, where a woman, in an IVF procedure, is implanted with her own egg fertilized by the intended father's sperm. There is also gestational surrogacy, in which a woman agrees to carry to term an IVF embryo conceived by a (married) couple, or by 
people related to her, and hand over the baby upon or shortly after delivery. With regard to the line of descent, the child of a surrogate mother could be genetically partly or fully related to the intended parents, or to the surrogate mother (if she is also the egg donor) and the intended father. ${ }^{42}$

To date, the literature has not investigated the genetic impact of the surrogate mother on the child, if she is not the egg donor, although research has proved that cell exchange occurs during pregnancy. ${ }^{43}$ However, one may ask in how far blood circulation, nutrition, and lifestyle habits during pregnancy may affect the baby's personality, and its physical and psychological development.

From the Islamic point of view, motherhood is established by birth (Qur'an 58:2). Legally, who is the mother of a surrogate child that is the product of an IVF with egg and sperm from second and third parties? This question has recently occupied a number of researchers, and their conclusions vary. $2,44,45$

Gestational surrogacy has existed since 1986. There is no global statistics on the number of children born into this situation. In the United States, it is reported that the number of gestational carrier cycles increased from 727 in 1999 to 3,432 in 2013. According to the American Society for Reproductive Medicine (ASRM), gestational carrier cycles during this period resulted in 13,380 deliveries, with a total of 18,400 infants being born out of these circumstances. ${ }^{46}$ This trend seems to be rising.

While the majority of Muslim scholars do not allow surrogacy due to the mixing of nasab and the resulting unclear status of the child's lineage, some scholars (mainly of the Twelver Shia school) allow surrogacy in case the surrogate mother and the egg donor are married to the intended father. ${ }^{42,44,47}$ The question of the establishment of motherhood, however, remains. Does the surrogate child in this case have two mothers, a genetic and a birth mother? The surrogate mother has debatably been compared to a foster mother in this case. $^{42}$

In contrast to the other scenarios discussed below, the case of surrogacy features some preliminary research on its psychological consequences. Van den Akker reports: infertile women voiced a spiralling of preferences to a part link, which was in turn preferred to no genetic link at all as in adoption. To some infertile couples, not having a genetic link at all was so unattractive that they were not prepared to consider that as a realistic option'. 48

There have been few long-term studies on the psychological effects of the process on surrogate mothers, or on children, or receiving parents, after the surrogacy process. Van den Akker revealed that surrogate mothers who expected some contact to continue between themselves and their families and the children after relinquishment of the baby felt betrayed when contact ceased abruptly. "Further longitudinal research on surrogate mothers is needed, and this should also address the well-being of the surrogate's own children. ${ }^{48}$ Existing studies report good mental and physical health of offspring.

A 10-year study by Jadva et al found that "surrogacy children showed higher levels of adjustment difficulties at age 7 than children conceived by gamete donation. Mothers who had kept their child's origins secret showed elevated levels of distress. However, maternal distress had a more negative impact on children who were aware of their origins." 49 The study concluded that "the absence of a gestational connection to the mother may be more problematic for children than the absence of a genetic link." 49 Another study by the same author suggested that children do not show significant adjustment problems by age $14 .{ }^{50} \mathrm{Jadva}$ et al in a longitudinal study reported on overall stable psychological well-being of surrogate mothers 10 years after relinquishing their baby. ${ }^{51}$ Does openness about the process towards the parties involved prevent negative societal and psychological impacts?

In the Islamic world, the Islamic Republic of Iran seems to be most experienced in the field of surrogate motherhood, given that the clerical elite subscribing to the Twelver Shia view on surrogacy, allows surrogate parenthood under conditions. In light of these experiences, Khalaf et al. conclude that, case studies have not noted any substantial psychological problems and surrogates have not experienced a higher than average postpartum depression rate, nevertheless, surrogate pregnancy should be treated as a high-risk psychological experience. ${ }^{52}$ The study recommended 
that surrogates receive professional counselling before, during and after pregnancy. ${ }^{52,53}$

As of 2006, the American Society for Reproductive Medicine reported 1,059 live surrogate births. ${ }^{54}$ The actual number may have risen considerably over the last two decades. Lahl contends that surrogacy is another form of the commodification of women's bodies and degrades a pregnancy to a service and a baby to a product. ${ }^{54}$ While there seems to be an absence of academic studies on children conceived as products of egg/sperm donation, the World Wide Web is replete with anecdotal evidence on its psychological and other complications. With the exception of the Iranian studies mentioned above, the long-term effects of surrogacy in the multiple combinations that exist (van den Akker lists 9 possible combinations), ${ }^{48}$ be it for the surrogate mother, child, commissioning parents or their relations, have hardly been researched. Although some similarities to adoption exist, an analogy is difficult to make.

\section{Scenario Three : IVF procedures with anonymous or extramarital donors}

The Islamic rule on IVF procedures is quite unanimous and clear cut in as far as IVF is considered permissible on condition that egg and sperm donor are married to each other and both alive at the time of the procedure. IVF procedures involving other than donors married to each other at the time of fertilization and implantation of the embryo are not permissible, for the obvious reason that any procedure involving unmarried donors is considered an unlawful mixing of nasab. ${ }^{35,36}$

Cases of fraud with regard to the identity of sperm donors or the origin of the sperm have recently been on the news. ${ }^{55}$ Moreover, with IVF procedure approximately one generation old, reports of children conceived by sperm donors attempting to trace their fathers, and children meeting their half-siblings who are products of IVF procedures, are becoming more common. These attempts may be significant for the underlying wish to know one's origins and know one's biological father and relations. Reports on half-siblings meeting testify to the existence of a family bond that has been cut, with people attempting to restore it, and the psychological stress they may go through in the process. ${ }^{56}$

\section{Scenario Four: Anonymous milk banks}

Milk banks are not an example somebody would immediately consider under questions of nasab; however, this example is relevant considering the particular Islamic focus on breastfeeding and the fact that foster kinship establishes the same rule as nasab with regard to marriage. Islamic law forbids (tahnim) marriage between the one who was breastfed as an infant and his wet nurse. This prohibition extends to a specified number of other persons, including the wet nurse's own children, her mother, grandmother, and siblings; her own husband and her husband's close relatives such as his children from other women, his siblings, and parents. Children being breastfed by the same woman also fall under the rule of tah $\bar{r} m .{ }^{57}$ Against this background, social and legal implications of establishing anonymous milk banks could be farreaching.

Milk banks, existent from the 1920s, have become increasingly popular due to the benefits of breast milk for babies and pre-term neonates. Milk from different donors is usually pooled, processed, and allocated to recipients without either sides knowing the identity of the other. ${ }^{57,58}$ As of 2020, anonymous milk banks are not operational in the Islamic world. ${ }^{59}$ There is textual evidence to forbid the procedure due to the legal implications of milk fosterage. The Prophet (pbuh) declared that "What is prohibited (for marriage) due to descent is also probibited by breastfeeding. "60

The question of unknown descent may not emerge with the same force in children who have been breastfed by the same woman than it is established in cases of, for instance, sperm donation. But given that the hadith establishes a prohibition of marriage in analogy to nasab, there may be more to the matter than we can currently perceive. Newer research suggests that breast milk expresses stem cells which do take over a vital role in the nursed child's system. ${ }^{61-63}$ Maternal stem cells expressed in breast milk can transgress the blood barrier in the infant's brain, although this may, according to the present state of research, not apply to the milk in anonymous milk banks if milk has been heated, pasteurized or frozen. ${ }^{62}$ 
A possible negative result of anonymized milk banks would be the (Islamically prohibited) marriage of men and women who have been nursed with the same milk, with unknown societal and psychological impacts. Should a genetic link between wet nursing mother and child be established, it would be of a lesser level than in IVF procedures or mitochodria tranplantation; on an embellishment level as compared to a level of necessities. We can also, for the time being, not establish that this expression of stem cells is the rationale ('illa) to legislate the prohibition of marriage between foster siblings. We may treat it as a hikma, or the wisdom behind the legislation. However, as the revealed text is definitive with regards to the prohibition of marriage between foster children, the discussion on the possible hikma does not impact the rule. This scenario may not be obvious with regards to possible psychological impacts of unknown descent. It does, however, showcase the intricate fabric of Islamic legal considerations and their wisdom, which may transcend human understanding at a certain period in time. As Islamic law considers wet nursing as a prohibitive factor to marriage on a par with nasab, with manifold legal and societal implications, it is legitimate to see this as a reminder to exercise caution with regard to our topic.

\section{Scenario Five: Mitochondria transplantation}

Mitochondria are known as "the powerhouse of the cell" because they provide most of the chemical energy in the cell. The mitochondrion has its own independent genome, containing 37 genes. They are inherited through the maternal side only. Mitochondria dysfunctions have been implicated in several diseases, including mitochondrial disorders, cardiac dysfunction, heart failure and autism. ${ }^{64}$

Embryonic mitochondria transplantation intends to replace the dysfunctional, unhealthy mitochondria of the intended mother, who is the only mitochondria carrier, with the healthy mitochondria DNA of a female donor. This may take place in two ways: i) through maternal spindle transfer (MST), where the mitochondria of the affected egg cell is exchanged with healthy donor mitochondria before fertilization. The procedure is to remove the nucleus from the egg cell of the mother-to-be, and then insert this nuclear DNA into an enucleated donor egg with healthy mitochondria. After IVF with the father's sperm, the embryo can be implanted into the mother's womb, resulting in a baby with nuclear DNA from each mother and father and mitochodria DNA from a female donor, the "third parent". ii) Pronuclear transfer (PNT) takes place after fertilization, where the parental DNA (the zygote) is transferred from a cell with unhealthy mitochondria to a fertilized donated egg with healthy mitochondria DNA from the "third parent" that is vacated of its zygote. Adult mitochondria transfer, to the best of our knowledge, has so far taken place in vitro only. ${ }^{64}$

Mitochondria transplantation is therefore a biomedical technique that leads to a mixing of genetic material. Children resulting from this procedure have been dubbed "three parent babies". It is so far unknown in which way the 37 mitochondria donor genes are expressed in the human body. However, from an Islamic point of view, the existence of a specified number of genes from a third party which are inherited to the next generations should be reason enough to prohibit the procedure.

The Islamic Fiqh Academy has recently ruled the nonpermissibility of the procedure, for reason of mixing of nasab, and a number of authors advise caution in the matter from a maqāsid-based Islamic bioethical approach. 65

It is not clear how far this or similar future procedures leading to human beings with three or more parents may impact the individual and society. The mixing of nasab in these cases is obvious, but can the psychological impact on individual and society be assessed at all? In analogy to anonymous IVF procedures, may it be expected that a spreading of this or similar techniques may lead to psychologically unsettled individuals?

The previously discussed scenarios have in common that these practices lead to a mixing or uncertainty of nasab on different levels of strength and with various legal implications. 


\section{CONCLUSION}

Psychological research has hardly asked the questions which we seek the answers to. This is most likely due to the predominantly secular worldview at its foundation. Existing research suggests that unknown descent or lack of clarity about descent does bring about psychological distress. It is to be expected that there may be, apart from the implications of more obvious Islamic legal rules with regard to marriage and inheritance, negative psychological and sociological effects of the increasing use of biomedical techniques leading to mixing or unclarity of nasab. If societies resort to such means of reproduction on a larger scale, with increasing numbers of children not knowing about their origins, a negative impact is to be expected.

The authors of this paper advise that more research needs to be channelled into the assessment of psychological and sociological impacts of unknown nasab due to the advances in the biomedical field. Research on the psychological effects of children, whether adopted or from surrogate mothers, not knowing their descent, may point to possible consequences of the other biomedical procedures featured above, but such research is not directly transferable to all of these cases. The dimensions of children not even being able to biologically trace their parents - as in three parent children (mt transfer) or cloning have not been researched. The increasing prevalence of anonymous milk banks is, within the secular context, not even an issue of debate.

The preservation of nasab is a priority of Islamic law, as many detailed legal rules reveal. This preservation is certain to also have a wisdom affiliated with it, next to the legal technicalities. Its neglect is expected to have negative consequences. Existing research, though scarce and not contextualized, does support this assumption. With regards to the discussed scenarios, we may conclude that, not only are the respective legal rules rendered moot or affected to various degrees of strength, but psychological and sociological effects of losing nasab in these cases are also to be expected.

The study has aimed to draw attention to the manifold consequences that the proliferation and acceptance of techniques leading to ambiguous descent will have on societies. It concludes that more research needs to be carried out to assess these consequences of new biomedical developments.

\section{CONFLICT OF INTEREST}

The authors of this paper declare no conflicts of interest. No funding was obtained for this paper.

\section{ACKNOWLEDGMENTS}

We would like to acknowledge Prof. Jan Oyebode of Bradford University, UK, for her guidance to important literature in the field.

\section{REFERENCES}

1. Kuwait Ministry of Awqāf and Islamic Affairs. Al -Mawsū'a al-fiqhiyya (Encyclopedia of Islamic Jurisprudence). Kuwait, 1995, 40:231-237.

2. Al-Jundī AN. Al-Nasab fì l-Islām wa l-arḥām albadîla [Lineage in Islam and surrogate wombs]. Cairo: Dār al-kutub al-qānūniyya, 2003.

3. Ghānim UI. Aḥkām al-janĪn fĪ l-fiqh al-islāmĪ. Jeddah: Dār al-Andalus al-khaḍrā' lil-nashr wa ltawzī'. 2001: 70.

4. Būgharāra Ṣ. Huquūq al-awlād fī l-nasab wa lhadāāna [Rights of children regarding lineage and rearing]. Alexandria: Dār al-fikr al-jāmì'̄i, 2013.

5. Al-Fayḍ̄i AA. Ahkām haquq al-janīn fī l-nasab: Dirāsa ta’șiliyya taḥlililiyya muqārana [Rules regarding lineage right of the fetus]. Cairo: Dār al -kutub al-qānūniyya, 2015: 129.

6. Ḥabīb MBI. Maqāṣid al-sharỉa al-islāmiyya ta'șillan wa tafîlan [Objectives of Islamic law]. Makkah: Dār țaibat al-khaḍrā', 2006.

7. Nyazee IAK. Islamic jurisprudence. Islamabad: International Institute of Islamic Thought (IIIT), 2000.

8. Kuwait Ministry of Awqāf and Islamic Affairs. Al -Mawsū'a al-fiqhiyya (Encyclopedia of Islamic Jurisprudence). Kuwait, 1995, 35:318.

9. Donovan K. A right to know one's parentage? Int J Law Policy Fam 1998; 2:27-45.

10. Blake L, Casey P, Reading J, Jadva V, Golombok S. 'Daddy ran out of tadpoles': How parents tell 
their children that they are donor conceived, and what their 7-year-olds understand. Hum Reprod 2010; 25:2527-2534.

11. Rowland R. The social and psychological consequences of secrecy in artificial insemination by donor (AID) programmes. Soc Sci Med 1985; 21:391-396.

12. Kirkman M. Parents' contributions to the narrative identity of offspring of donor-assisted conception. Soc Sci Med 2003; 57: 2229-2242.

13. Bharadwaj A. Why adoption is not an option in India: The visibility of infertility, the secrecy of donor insemination, and other cultural complexities. Soc Sci Med 2003; 56:1867-1880.

14. Wellisch E. Children without genealogy - a problem of adoption. Mental health London 1952. 12(1): 41-42.

15. Sant HJ. Genealogical bewilderment in children with substitute parents. Brit J Med Psychol 1964; 103:133-142.

16. Leighton $\mathrm{K}$. Addressing the harms of not knowing one's heredity: Lessons from genealogical bewilderment. Adopt Culture 2012; 3:63-107.

17. Humphrey M, Humphrey H. A fresh look at genealogical bewilderment Brit J Med Psych 1986; 59:133-140.

18. Ravitsky V. The right to know one's genetic origins and cross-border medically assisted reproduction. Israel J Health Pol Res [online] 2017; 6:3. Available at: https:// www.ncbi.nlm.nih.gov/pubmed/? term $=$ Ravitsky $\% 20 \mathrm{~V} \% 5 \mathrm{BAuthor} \%$ 5D\&cauthor=true\&cauthor_uid $=28105298$

19. Janoff-Bulman R. Shattered assumptions: Towards a new psychology of trauma. New York: Free Press, 1992.

20. Parkes CM. What becomes of redundant world models? A contribution to the study of adaptation to change. Brit J Med Psych 1975; 48:131-137.

21. Bruce N. On the importance of genetic knowledge. Child Soc 1990; 4:183-196.

22. ASRM (Ethics Committee of the American Society for Reproductive Medicine). Informing offspring of their conception by gamete or embryo donation: A committee opinion. Fertil Steril 2013; 100:45-9.
23. Symons $\mathrm{X}$. The right to know vs the right to privacy: Donor anonymity and the Assisted Reproductive Treatment Amendment Act 2016 (Vic). Med J Austral 2017; 207:377-378.

24. Blyth E. Being a child of donor insemination. BMJ 2002; 324:1339. PMCID: PMC1123290.

25. Blyth E. Discovering the 'facts of life' following anonymous donor insemination. Int J Law Pol Fam 2012; 26:143-161.

26. McGee G, Vaughan S, Brakman A, Gurmankin D. Gamete donation and anonymity: Disclosure to children conceived with donor gametes should not be optional. Hum Reprod 2001; 16: 2033 2036.

27. Meerum Terwogt M, Meerum Terwogt-Reijnders CJ, van Hekken SMJ. Identity problems related to an absent genetic father. SSOAR (Social Science Open Access Repository). Zeitschrift für Familienforschung 2002; 14:257-271.

28. Tieman W, van der Ende J, Verhulst FC. Young adult international adoptees' search for birth parents. J Fam Psych 2008; 22:678-687.

29. Sobol MP, Cardiff J. A sociopsychological investigation of adult adoptees' search for birth parents. Fam Rel 1983; 32:477-483.

30. Bertocci D, Schechter MD. Adopted adults' perception of their need to search: Implications for clinical practice. Smith Coll Stud Soc Work 1991; 61:179-196.

31. Müller U, Perry B. Adopted persons' search for and contact with their birth parents I, Adopt Quar 2001; 4:5-37.

32. Müller U, Perry B. Adopted persons' search for and contact with their birth parents II, Adopt Quar 2001; 4:39-62.

33. Jadva V, Freeman T, Kramer W, Golombok S. Experiences of offspring searching for and contacting their donor siblings and donor. Reprod Biomed 2010; 20:523-532.

34. McWey LM., Acock A, Porter B. The impact of continued contact with biological parents upon the mental health of children in foster care. Child Youth Serv Rev 2010; 32:1338-1345.

35. Islamic Fiqh Academy. Resolutions and recommendations of the Council of the Islamic Figh Academy 1985-2000. Jeddah: Islamic Development Bank, 2000. 
36. Atighetchi D. Islamic bioethics: Problems and perspectives. Dordrecht: Springer, 2009.

37. Al-Qaradāghī A. Al-Istinsākh min manẓūr al-fiqh al-islāmī [Cloning from an Islamic perspective]. http://www.qaradaghi.com/chapterDetails.aspx? ID=178. Accessed 15 May 2020.

38. Bouzenita AI. Changing creation or harnessing nature: The reception of biotechnology in the Islamic world. Islam Stud [Islamabad] 2009; 48:499-523.

39. Walker S. Biotechnology demystified. New York: McGraw Hill, 2007.

40. 'Ārif, AA. Masā’il shar'iyya fĪ l-jĪnāt al-bashariyya [Islamic legal case studies on human embryos]. Kuala Lumpur: IIUM Press, 2011.

41. MacIntosh KL. Cloning: Four fallacies and their legal consequences. Cambridge Bioethics and Law, 2011.

42. Sachedina AA. Islamic biomedical ethics: Principles and application. New York: Oxford University Press, 2009.

43. Barinaga M. Cells exchanged during pregnancy live on. Science 2002; 296:2169-2172.

44. Shabana, A. Foundations of the consensus against surrogacy arrangements in Islamic law. Islam Law Soc 2015; 22:82-113.

45. Saljoughi, M. Surrogacy in Iranian law. A comparative and evaluation study based on Islamic jurisprudence [PhD Thesis]. Kuala Lumpur: International Islamic University Department of Fiqh and Usul al-Figh, 2019.

46. Surrogate Solutions. Gestational surrogacy stats in the United States [Blog article]. 2017 Nov 24. Available at: https://

www.surrogatesolutions.net /2017/11/24/ gestational-surrogacy-stats-united-states. Accessed 20 December 2019.

47. Muaygil R. Reexamining the prohibition of gestational surrogacy in Sunni Islam. Devel World Bioethics 2017; 17:112-120.

48. van den Akker OBA. Psychological aspects of surrogate motherhood. Hum Reprod Update 2007; 13:53-62.

49. Jadva V, Blake L, Casey P, Golombok S. Surrogacy families 10 years on: Relationship with the surrogate, decisions over disclosure and children's understanding of their surrogacy origins. Hum Reprod 2012; 27: 3008-3014.

50. Golombok S, Ilioi E, Blake L, Jadva V. A Longitudinal Study of Families Formed Through Reproductive Donation: Parent-Adolescent Relationships and Adolescent Adjustment at Age 14. Develop Psych 2017; 53 (10):1966-1977.

51. Jadva V, Imrie S, Golombok S. Surrogate mothers 10 years on: a longitudinal study of psychological well-being and relationships with the parents and child. Hum Reprod 2015; 30:373 -379 .

52. Khalaf FZ, Shafiabadi A, Tarahhomi M. Psychological aspects of surrogate motherhood. J Reprod Infert 2008; 9:43-49.

53. Ahmari TH, Tashi S, Mehran N, Eskandari N, Tehrani TD. Emotional experiences in surrogate mothers: A qualitative study. Iran J Reprod Med 2014; 12:471-480.

54. Lahl J, director. Breeders: A Subclass of Women? [documentary film] 2014. https://ifstudies.org/ $\mathrm{blog} /$ the-overlooked-risks-of-surrogacy-forwomen. Accessed 21 November 2019.

55. BBC News. Dutch fertility doctor used own sperm to father 49 children, DNA tests show. BBC News 2019 Apr 12. https://www.bbc.com/ news/world-europe-47907847. Accessed 15 January 2020.

56. Peterson P. He found out he had 32 siblings. For the Times Magazine, he took their pictures. The New York Times 2019 Jun 29. https:/ / www.nytimes.com/2019/06/29/reader-center/ sperm-donor-siblings.html

57. Bouzenita AI. Milk banks. In: The Encyclopedia of Islamic Bioethics. Oxford Islamic Studies Online. 13 Jun 2019. http:// www.oxfordislamicstudies.com / article/opr/ t9002/e0315

58. Bouzenita AI. Islamic perspectives on milk banks and their usage by Muslims. Waikato Islam Stud Rev 2016; 2:4-18.

59. Bāhāàmid I. Bunūk al-mustakhrajāt al-bashariyya

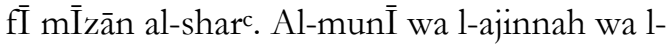
halīb [Human extracts banks on the scale of shari'a: Sperm, embryos and milk]. MA thesis. Sultan Qaboos University, 2020.

60. al-Nīsābūrī MH. Hadith 1445. Șaḥịh Muslim, n.d. https://www.dorar.net/ 
h/904e5e48be925f3a4db83e522b4bef69

61. Michie CA. The long-term effects of

breastfeeding: a role for the cells in breast milk? J

Trop Ped 1998; 44:2-3.

62. Hassiotou F, Mobley A, Geddes DT, Hartmann

PE, Wilkie T. Breastmilk imparts the mother's stem cells to the infant. FASEB Journal 2015;

29:876.

63. Aydin MS, Yiğit EN, Vatandaşlar E, Erdoğan E, Öztürk G. Transfer and integration of breast milk stem cells to the brain of suckling pups. Scient Rep 2018; 8:14289.

64. Bouzenita AI, Mirghani MES, Jaswir I. The Islamic ethics of mitochondria transplantation. IIUM J Eng 2017; 42-46.

65. Ibrahim AH, Rahman NNA, Saifuddeen SM, Baharuddin M. Tri-parent baby technology and preservation of lineage: An analysis from the perspective of maqasid al-Shari'ah based Islamic bioethics. Sci Eng Ethics 2019; 25:129-142. 